\title{
Public BIM-based model checking solutions: lessons learned from Singapore and Norway
}

\author{
E. Hjelseth \\ Department of Civil Engineering and Energy Technology, \\ Oslo and Akershus University College of Applied Sciences, Norway
}

\begin{abstract}
There is an increasing interest for BIM-based model checking in general. The use of public solutions for building permit approval is often highlighted as an example of practical use of BIM. A global spread of these solutions could therefore have been expected. However, implementations in other countries have been limited. This study analyses the Corenet solution in Singapore and the ByggSøk solution in Norway in respect of identifying experiences that can be useful for other countries that intend to develop their own solutions. Use of the Integrated Design and Delivery (IDDS) framework from CIB helps to explain elements with an impact on implementation of the solution. This type of explanation is often missing when presenting or comparing solutions. The impact of this study is increased understanding of knowledge transfer and awareness of which elements can be re-used from others in national implementations.
\end{abstract}

Keywords: model checking, BIM implementation, maturity, knowledge transfer.

\section{Introduction}

BIM-based model checking (BMC) is highlighted as one of the most significant benefits for use of building information modelling (BIM) [1]. Use of BMC in the industry is mostly related to coordination of disciplines and clash control. Use of BMC can serve as an indicator of maturity for BIM in projects [2]. The public authority plays an important role as a catalyst to initiate development. National authorities have a special role in implementing BMC [3]. Building permit approval is a mandatory point for every construction project - and in this respect an obvious 
candidate for BMC. The number and type of users is direct related to the number of building permit applications - so the number of "customers" of the solution is therefore been know in advance. National authorities have resources to develop solutions or adapt existing solutions. Large numbers of implementations in many countries should therefore have been expected due to its role as mandatory task in all construction projects.

However, this is not the situation - the number of implementations is limited. This raises the question: "What can be learned from the pioneers?" and why do we not see the expected numbers of implementations?

National public digital solutions for processing building applications are not common service. Lack of common international terms makes it hard to discover potential solutions in other countries [4]. The Norwegian Building Authority developed the "ByggSøk" (Building Application) solution in 2007 [5, 6]. This is a web-based solution for verification of filled-in application forms related to specific types of applications. They plan to develop a more sophisticated solution called "ByggNett" [7]. The "CORENET" e-Submission System from 1995 in Singapore is well known [8]. These implementations will be used as cases in this paper. Other examples on digital solutions for support of building permit applications can be the "Planning portal" from the UK Government's online planning and building regulations resource for England and Wales [9]. Korea is developing the Seumter Code Checking System based on research at the KyungHee University [10]. This list is not comprehensive, but indicates limited number of implementations.

Digital service can be expected to be faster and cheaper than manual processing. Upon closer inspection, this is most important in smaller projects where the fee has higher ratio compared to design time and project cost. However, maybe the qualitative improvements resulting in more predictable outcome is the most important impact. The ability to use BMC during the design process can have a significant impact on the design of buildings. Likewise national building authority can use digitalization during development of new regulations. BMC can be used to explore consequences of new regulations and to identify interactions between different regulations [11].

An international survey by the Norwegian Building Authority [5] pointed out the following benefits of automatic assessment systems:

- Equal requirements for information for all local authorities

- $\quad$ Equal assessment for information for identical types of projects

- $\quad$ Digital information enables reuse for other purposes

- Solutions for pre-check of application in advance of formal submission

- $\quad$ Support for design according to the regulations

Dr. Tan Kee Wee and Cheng Tai Fatt at the Building Construction Authority in Singapore believe that development of an automatic compliance-checking platform will return ten times the investment required [5].

Table 1 presents a Norwegian survey by the Norwegian Building Authority [5] identifying the four most important barriers and drivers for the adoption and implementation of BIM: 
Table 1: Important BIM drivers and barriers [5].

BIM-DRIVERS:

- Requirements from public project owners

- Requirements from building authorities

- Effective and agile design process

- Job satisfaction and recruitment
BIM-BARRIERS:

- Conservative culture

- Fragmented industry

- Lack of competence

- Current contractual standards

\section{Methodology}

This study uses Norway and Singapore as cases for exploring implemented public digital solutions for processing of building permit applications. The traditional perspective has been on technology and exchange of BIM/openBIM files. Technology is an important enabler. However, this approach does not explain or provide understanding for why these implementations have not reached global spread.

This study introduces a wider approach than technology and looks into missing perspectives. In this respect, the Integrated Design and Delivery (IDDS) framework from International council for research and innovation in building and construction (CIB) has been used to explain elements with an impact on implementation of solutions. This type of explanation is often missing when presenting or comparing solutions. IDDS is a priority theme in CIB, initiated in 2006. The IDDS is comprehensive presented in CIB Publication 370 [12] in 2013, with summary in CIB Publication 373. The first version presented was CIB Publication 328 in 2009. The IDDS framework is based on three core perspectives; People, Process and Technology - expressed as: Collaborating people, Integrated process and Interoperable technology [12]. This perspective is clarified by the three imperatives: Building Information Modelling, Knowledge management and Integrated project delivery as presented in Figure 1.

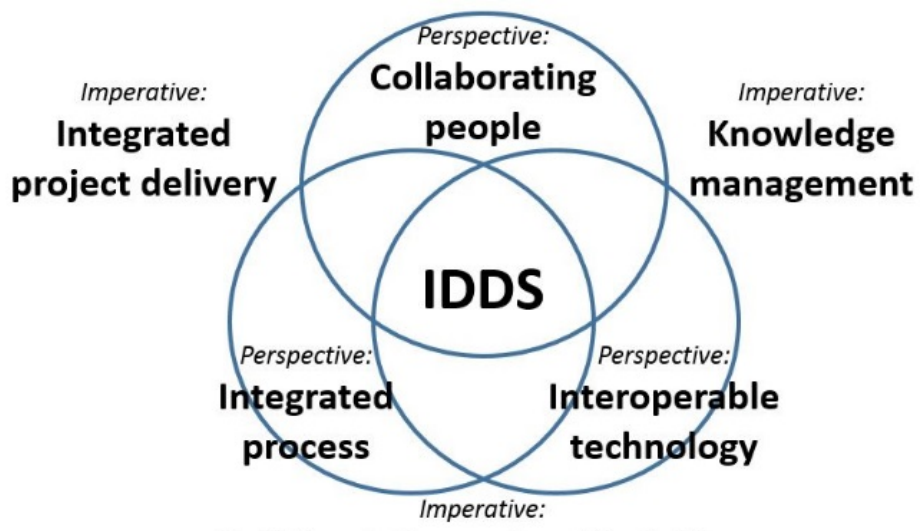

Building Information Modelling

Figure 1: The three perspectives and the three imperatives in IDDS [12]. 
In this study are the three perspectives interpreted with a focus on digital processing of building applications:

Integrated process:

Processes and requirements related to preparing, this includes both the applicant and the building authority.

Collaborating people:

Focuses on the background assumption for people's actions. BIM maturity, competence and tacit knowledge is a part of this perspective.

Interoperable technology:

Include presentations of the technical solutions and exchange of information.

There is a connection, direct or indirect, between all three perspectives. The importance of focus on the relationships in the IDDS framework can be illustrated by using one perspective to obtain effect on components in one or both or the other perspectives [13]. This approach can contribute to enable change is design of solution and realization of change in practice. The success of development should therefore be measured by its capacity to create change. Focus should therefore not be on the deliverables from the project, but the impact of practical use [14]. The importance of focusing on collaborative BIM use has also been pointed out in reviews [15].

These perspectives; Collaborating people, Integrated process and Interoperable technology [12] are used to structure the cases from Norway and Singapore. The status of these three perspectives is based on literature reviews.

\section{Case: Norway}

\subsection{Integrated process}

Building permit application process in Norway is presented in Figure $2[5,16]$. This process have direct and indirect influence on a long range of elements and is therefore a good introduction for understanding of all components and relations.

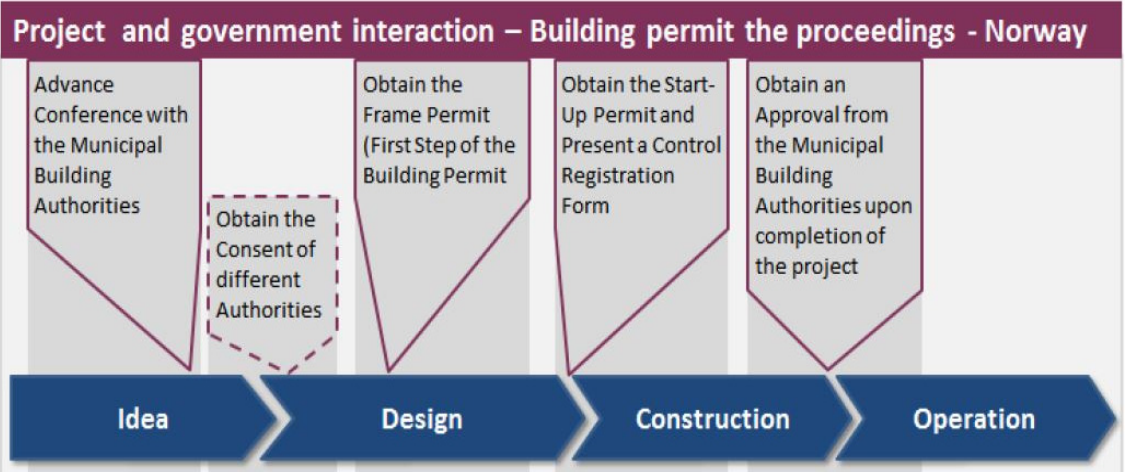

Figure 2: Building application and permit process in Norway $[5,16]$. 
In 2012 there were approximately 110,000 applications submitted to the local building authority. Approximately $37 \%$ were submitted as paper-based forms (completed manually on paper, or as print-outs of PDF forms completed manually on the computer). ByggSøk was used as a tool for completing approx. 70,000 (63\% of total) applications. Figure 3 shows the distribution of ByggSøk services from 2005 to 2012 [4].

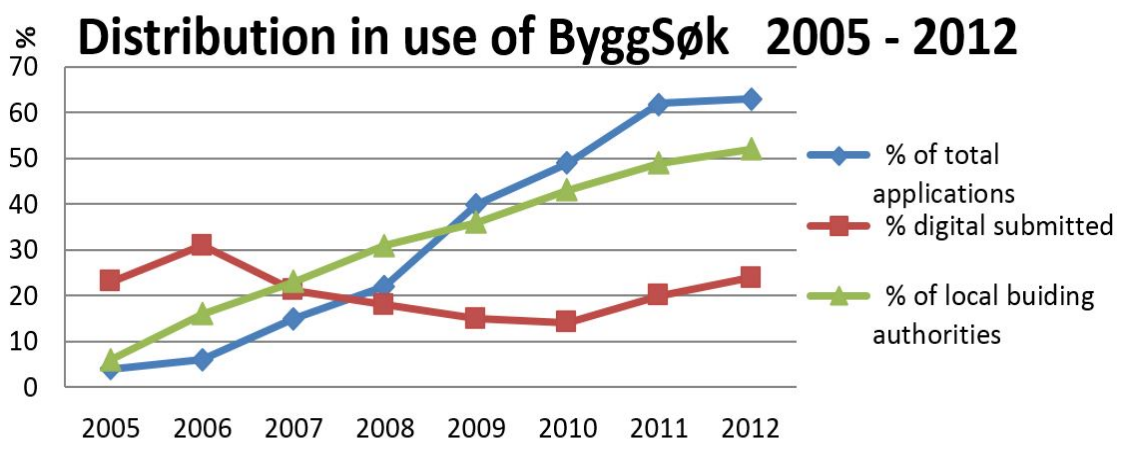

Figure 3: Distribution in use of ByggSøk 2005-2012 [4].

The processing of all applications submitted by ByggSøk is processed at one of the approximately 330 local building authorities in the same way as traditional applications using paper forms. The total number of building officers in Norway is approximately 1500 employees, varying from one part-time up to 440 in the capital.

The building permit application from ByggSøk can be submitted as:

- $\quad$ Printout on paper, sent by ordinary mail/delivered manually to local building authority office. This enables the supplement of paper drawings and other documents.

- Digital files over the internet. The application forms as one single PDF file, in addition to an XML structured file. Supplementary documents and drawings must be attached as PDF files. There is an option for submitting additional documents/drawings by mail. The processing does not start until the local building authority receives this.

Figure 3 illustrates an increase in use of ByggSøk as a tool for preparing the application. However, the percentage of digital submission has not increased. The Norwegian Building Authority points out two perspectives as possible explanations:

- Applicant: A large number of documents from many sources must be digitized. ByggSøk is only used to ensure that all relevant forms are filled in. There are no added benefits (reduced fee, shorter processing time) for $100 \%$ digital applications. ByggSøk is used as an advanced "application writer" with input validation of fields in the form (but no validation of content).

- Local building authority: Lack of system to process the applications in a digitized way (XML-import and use of digital attachment). Received applications are printed out and processed manually [6]. 
The climate and population set some constraints for the construction industry. Norway's climate has very large variations, both during the year and from north to south. This constraint influences both the buildings and their construction, in addition to working conditions and need for local adaptation of the buildings. The building authorities do not check technical specification, but the legislation requires that the design and construction is performed by qualified companies [17].

\subsection{Collaborating people}

The AEC industry is the second largest sector in Norway in terms of revenue and number of employees. The Norwegian AEC industry included 54,982 companies, 219,598 employees and $€ 48.1$ billion in turnover in 2013. The turnover has increased by $40 \%$ since 2009 [18]. The revenue for the hundred largest companies is approximately $30 \%$ of the total revenue for the AEC industry in Norway. This is the result of an industry that is fragmented, consisting of numerous small companies. $95 \%$ have 5 or fewer employees, $1 \%$ of companies have more than 50 employees, and $90.9 \%$ have under 10 employees [18]. The Norwegian population is 5.1 million on an area of $385.178 \mathrm{~km}^{2}$, resulting in 15 people $/ \mathrm{km}^{2}$. This influenced the size of buildings and what the society give priority [17].

Adoption of BIM in the Norwegian AEC industry has come a long way in a relatively short period of time. BIM is today in use in most large construction projects. Especially public project owners have awareness and are requiring architects, engineers and contractors to use BIM. Architects and engineers have adopted BIM to a greater extent than contractors and Facility management (FM) professionals. Furthermore, the building construction sector seems to be more mature than the infrastructure sector, which to a greater extent is reliant on proprietary solutions. In addition to traditional design tasks, BIM is used for collision control, energy analysis and extraction of quantity for cost calculation.

The last five to ten years, the adaptation of BIM has increased greatly in Norway. Architects are the primary adopters, followed by engineers and contractors. Most large construction projects are currently designed using BIM. In addition to traditional design tasks, BIM is used for collision control in the design phase and the production of quantity-related data for cost calculation. During onsite construction, BIM is used to a small extent. The same goes for BIM use in the building operation phase [5].

\subsection{Interoperable technology}

ByggSøk is the Norwegian solution for electronic communication in building application processing. The first version was launched on July 1, 2003. The development lasted for three years and the cost was about 2 million Euro (2003 rate). With ByggSøk, the builder can fill out the application and send it via the internet. The current version (Version 3.2) was launched on January 7, 2013. The technical specification of ByggSøk was drawn up internally by the Norwegian Building Authority [6].The application is based on EXPRESS Data Manager ${ }^{\mathrm{TM}}$ (EDM) from Jotne EDM Technology in Norway. The system is an object database with tools to manage complex product data models. EDM can resolve data 
interoperability issues like exchange, sharing, integration, quality and archival. HTML, PDF, FTP and XML files can be exported. ByggSøk has a three-layer architecture: database, server application and user interface. The system uses a primary SQL database with transaction support. Any data exchange is done using the XML format [5].

ByggNett is a new strategy for digitalization of the entire construction related industry. This include public sector. Further development of ByggSøk with extended services for processing of building permit applications will be an important part of the new ByggNett strategy. The level of service and complexity is illustrated in Figure 4 [4].



Figure 4: Development progress of the Norwegian solution [4].

The overall vision for the ByggNett strategy is simple, effective and predictable services throughout the life cycle of the built environment. The strategy indicates development of an integrated, complete solution for processing of building applications. This includes services for both the local public building authority office processing the application and for the applicant, professional or private, submitting the building permit application. There is an increased gap between Step 3 and 4 in Figure 4 to illustrate this step is demanding. Step 4 can be related to Level 3 in the UK strategy for digitalisation of the entire construction industry [19, 20].

The activities and measures in the ByggNett strategy [7] are based on three basic guidelines:

- User orientation

- Do-It-Yourself service

- Collaboration

The strategy will ensure the best possible relationship between different initiatives and achieve their goals in both the short and long term. The strategy describes five priority areas for development of: 
- $\quad$ Relationships with industry and other authorities

- Processes and methodologies that support digitization

- Competency

- Regulations applicable for digitalisation, and

- Services and tools, applications and registry for storing, processing, sharing and presentation of information.

Implementation of this strategy is challenging because it affects many "players". Due to this complexity, will implantation of the strategy focus on a series of small projects, instead of one large project or one comprehensive software solution [7].

\section{Case: Singapore}

\subsection{Integrated process}

Building permit application process in Singapore is presented in Figure 5 [5, 21]. This process have direct and indirect influence on a long range of elements and is therefore a good introduction for understanding of all components and relations.



Figure 5: Building application and permit process in Singapore [5, 21].

e-Submission is mandatory: In Singapore, almost $100 \%$ of planning applications are now performed on the e-Submission System. With a customer base of over 2,500 companies, it is used widely by architects, engineers, surveyors, plumbers, electricians and other professionals. In an industry survey, $89 \%$ of the respondents indicated they had experienced cost and time savings related to printing of plans, transportation/dispatch services and increased staff productivity. Adoption of the e-Information System is similarly widespread, with a user base of over 12,000 industry professionals, resulting in the gradual phasing-out of printed copies of circulars and correspondence by the participating regulatory departments [5]. An overview of approved plans in 2014 [22] is listed in Table 2. 
Table 2: Listing of approved plans in 2014 [22].

\begin{tabular}{lc}
\hline Type or application/approval & Number \\
\hline Approved Building Plans & 4,402 \\
Approved CD Shelter Plans & 2,917 \\
Approved Structural Plans & 16,614 \\
Permits to Commence Structural Works Issued & 6,381 \\
\hline
\end{tabular}

Temporary Occupation Permits (TOP) Issued and Certificates of Statutory Completion (CSC) are part of the Norwegian building application in reporting finalized projects. These numbers are not relevant in relation to the Norwegian process.

\subsection{Collaborating people}

Construction contracts for the built environment sector are expected to reach between $€ 19.7$ billion to $€ 23.8$ billion in 2015 , given a sustained pipeline of public sector projects. This follows an exceptionally strong performance in 2014 where the total construction demand set a new record of $€ 24.8$ billion, fuelled by a higher volume of institutional and civil engineering construction contracts [23]. The AEC industry in Singapore consists primarily of labour migrants in terms of building workers. Overall, 300,000 work permits were granted for migrant workers in the construction industry in June 2013. The high proportion of labour means that the industry is slowing, taking productivity into account. The government has initiated a program for productivity improvement [24]. The population is 5.5 million on an area of $718 \mathrm{~km}^{2}$, resulting in 7,615 people $/ \mathrm{km}^{2}$ [25]. Tall buildings are dominating - enabling professional roles in the design and application process. Singapore has a tropical rainforest climate with no distinctive seasons, uniform temperature and pressure, high humidity, and abundant rainfall. Temperatures usually range from 22 to $35^{\circ} \mathrm{C}[25]$.

The adoption of BIM in Singapore is estimated at 65\%. Most of the AEC industry players are using AutoDesk solutions. The Singapore Building Construction Authority's approach to industry adoption of BIM is based on a topdown philosophy. According to Dr. Evelyn Teo at the University of Singapore, the driving forces behind the implementation and adoption of BIM in Singapore are strong economic incentives and education. The technology is mature and available; it is the soft human aspects of organization, culture and adoption of the technology that are the real challenges. In 2010 the Building and Construction Authority (BCA) in Singapore launched the BIM roadmap. This is intended to increase productivity and the level of integration among the various stakeholders in the AEC industry. The goal is that $80 \%$ of the AEC industry should be using BIM by 2015. Singapore is currently focusing on open BIM. Though progress is moving slowly, supporters believe that non-proprietary solutions represent the only way to resolve interoperability issues [5]. 


\subsection{Technology}

The idea of an artificial intelligence planning checking system was first conceived of in Singapore as early as 1982. In 1995 the Ministry of National Development of Singapore, with the Building and Construction Authority as implementing agency, initiated CORENET (Construction and Real Estate Network) [26]. In 2002 CORENET was upgraded and the 2D BP Expert System replaced with the 3D IFC data model. The application is based on FORNAXTM from novaCITYNETS. Fornax is an IFC viewer developed for the ePlanCheck project in the CORENET program. FORNAX ${ }^{\mathrm{TM}}$ was developed specifically to perform automated checks on electronic drawings against building and land regulations for design compliance and to generate compliance reports. It extends the IFC models and builds additional intelligence to enable the implementation of checking functions. The FORNAX ${ }^{\mathrm{TM}}$ software platform was developed by novaCITYNETS. At the base of the FORNAX ${ }^{\mathrm{TM}}$ software are [5]:

a) database technology from EPM Technology A/S;

b) an ACIS library from Spatial Corp;

c) Open Cascade technology from Open Cascade; and, most importantly,

d) Industry Foundation Classes (IFC) Release 2x2 from BuildingSMART IAI International.

CORENET currently has three services: e-Submission, e-PlanCheck and eInfo.

The e-Submission System has been up and running as an electronic service since early 2002. Involving the 16 regulatory authorities across eight government ministries that regulate the construction and real estate industry, it facilitates collaboration among the various regulatory authorities. By allowing industry professionals to submit and monitor the progress of planning applications over the Internet, e-submission serves as a single government counter, available non-stop on a $24 \times 7$ basis. Industry professionals today do not need to make hard copy prints of building plans or take physical trips to the authorities. Transparency has also been improved, as all stakeholders can monitor the status and progress of planning applications online. As part of the project, government processes have been streamlined to improve efficiency and customer experience. e-Submission is based on PAVOTM, a suite of the J2EE application, which enables submission logichandling and rules validation. It provides built-in business intelligence and secure transmissibility [5].

The e-PlanCheck initiative is the most ambitious part of CORENET. The process allows designs for new buildings to be digitally checked against building codes, using automated procedures, rather than manual paper-based processes. Involving eight regulatory authorities from five government ministries, the project will be rolled out in phases, starting with architectural works and building services. e-PlanCheck has been implemented on top of FORNAXTM, a software platform developed by novaCITYNETS, which extends the IFC models and builds additional intelligence to enable the implementation of checking functions. As the name suggests, checking functions are the core functionality of the e-PlanCheck system. At the base of the FORNAX ${ }^{\mathrm{TM}}$ software are: (a) database technology from 
EPM Technology A/S; (b) an ACIS library from Spatial Corp; (c) Open Cascade technology from Open Cascade; and, most importantly, (d) Industry Foundation Classes (IFC) Release 2x2 from BuildingSMART International. With IFC 2x2 as a base, a layer of FORNAX ${ }^{\mathrm{TM}}$ objects were built. These FORNAX ${ }^{\mathrm{TM}}$ objects are enhancements to the IFC $2 \times 2$ model. These objects provide richer information, which is required for the implementation of checking functions in the system. In order for the system to perform checks successfully, qualified persons submitting plans need to use CAD software that has been certified as capable of producing the IFC $2 \times 2$ model data expected by the system. This data is complemented by client-side functions that capture the additional information required by the checking functions. UK consultancy company AEC3 provided model development assistance to the Singapore government [5].

The e-Info System, available since 2002, provides a comprehensive central repository for building and construction-related information in Singapore, presented in a single format via a single portal on the Internet. The integrated information channel provides a quick and easy source of reference, doing away with the need for industry professionals to maintain hard-copy reference materials. Email broadcasts are also available to alert users to new information and updates on the portal. Supported by 13 regulatory organizations across seven government ministries, e-Info offers information on codes, regulations, guidelines, standards, product catalogues, contractors' performance and Singapore standards. By leveraging the XML technologies, e-Info stores and describes information in a machine-interpretable format that can be processed and understood easily by different IT applications. Apart from allowing seamless communication, the content can be used by different Internet-based e-business applications. At the same time, the removal of machine dependency means the life and value of information in e-Info can be better preserved and extended. During earlier development, CORENET (BP Expert System) experienced problems related to lack of 3D CAD customized to Singapore's data format and the consequent high cost of sustaining local customization efforts. Building and Construction Authority has decided that full development will be based on the IFC standard [5].

\section{Exploring Norway and Singapore by the IDDS framework}

Table 3 gives an overview of the situation in Norway and Singapore in terms of the IDDS framework. It is the relations between the three perspectives; Integrated processes, Collaborating people, and Interoperable technology, that are relevant.

Table 3 represent overview of components from the Norwegian and the Singapore solution for digital processing of building permit applications. The overview illustrates both similarities and differences between Norwegian and Singapore solutions, but is does not identify any components that alone explain the success of both solutions. Even if both solutions use model sever technology, this is implanted very differently. The overview do not identify whether if the connection between the components are direct, indirect or absent.

The IDDS framework indicates that the success of both solutions can be explained by based on the balance between the perspectives and adaptation of 
Table 3: Exploring Norway and Singapore through the IDDS framework.

\begin{tabular}{|c|c|c|}
\hline IDDS & Norway & Singapore \\
\hline \multicolumn{3}{|l|}{ Integrated processes } \\
\hline $\begin{array}{l}\text { Number of application } \\
\text { processed pro year }\end{array}$ & $\begin{array}{l}\text { High } \\
\text { Approx. } 110,000\end{array}$ & $\begin{array}{l}\text { Low } \\
\text { Approx. 4,500 }\end{array}$ \\
\hline States of involvements & $\begin{array}{l}\text { Start early in the } \\
\text { application process } \\
\text { - Idea phase }\end{array}$ & $\begin{array}{l}\text { Limited } \\
- \text { End of design phase }\end{array}$ \\
\hline Demand for BIM & Large public projects & For building applications \\
\hline $\begin{array}{l}\text { Validation of technical } \\
\text { solutions }\end{array}$ & $\begin{array}{l}\text { Not checked by the } \\
\text { authority }\end{array}$ & $\begin{array}{l}\text { Checked as part of the } \\
\text { application }\end{array}$ \\
\hline $\begin{array}{l}\text { Role of "drawings"/ } \\
\text { models }\end{array}$ & $\begin{array}{l}\text { Limited, } \\
\text { External aspects; } \\
\text { heights, area, and } \\
\text { distance to other } \\
\text { buildings, infrastructure }\end{array}$ & $\begin{array}{l}\text { Important to check } \\
\text { technical requirements, } \\
\text { fire safety. } \\
\text { Flexible view of section } \\
\text { in model is important }\end{array}$ \\
\hline $\begin{array}{l}\text { Scope of content/ } \\
\text { perspective in } \\
\text { application } \\
\text { Technical }\end{array}$ & $\begin{array}{l}\text { No checking technical } \\
\text { solution - Requirements } \\
\text { addressed to responsible } \\
\text { company } \\
\text { Only focus on process }\end{array}$ & $\begin{array}{l}\text { Comprehensive } \\
\text { checking of technical } \\
\text { requirements } \\
\text { Fire, Technical solutions }\end{array}$ \\
\hline Legislation & Comprehensive & Comprehensive \\
\hline $\begin{array}{l}\text { Legislation type, Act, } \\
\text { Code, Guidance level }\end{array}$ & $\begin{array}{l}\text { Function based, with } \\
\text { some prescriptive } \\
\text { guidelines }\end{array}$ & $\begin{array}{l}\text { Prescriptive based } \\
\text { (mostly), some function } \\
\text { based requirements }\end{array}$ \\
\hline $\begin{array}{l}\text { Size of project in the } \\
\text { application }\end{array}$ & $\begin{array}{l}\text { Variation, mostly small } \\
\text { private projects }\end{array}$ & $\begin{array}{l}\text { Large professional } \\
\text { projects dominate }\end{array}$ \\
\hline $\begin{array}{l}\text { Number of offices } \\
\text { processing the } \\
\text { application }\end{array}$ & $\begin{array}{l}\text { Many, approx. } 330 \text { local } \\
\text { building offices (in most } \\
\text { municipalities) }\end{array}$ & One central office \\
\hline $\begin{array}{l}\text { Size of building } \\
\text { authority approving } \\
\text { applications }\end{array}$ & $\begin{array}{l}\text { High variation; } \\
1500 \text { people total in } \\
\text { Norway, from } 1 \text { part } \\
\text { time employee to } 440 \\
\text { employees in the capital. }\end{array}$ & Large, one central office \\
\hline \multicolumn{3}{|l|}{ Collaborating people } \\
\hline Structure of industry & $\begin{array}{l}\text { Fragmented, small } \\
\text { companies under } 10 \\
\text { employees dominate }\end{array}$ & $\begin{array}{l}\text { Large companies, large } \\
\text { commercial projects }\end{array}$ \\
\hline Application produced by & $\begin{array}{l}\text { Private applications } \\
\text { dominate in numbers }\end{array}$ & Commercial companies \\
\hline $\begin{array}{l}\text { Role definitions } \\
\text { Responsible applicant }\end{array}$ & $\begin{array}{l}\text { No professional } \\
\text { requirements, role only } \\
\text { as contact person }\end{array}$ & $\begin{array}{l}\text { Certified operator, } \\
\text { profession role }\end{array}$ \\
\hline $\begin{array}{l}\text { Importance of } \\
\text { construction industry for } \\
\text { national economy }\end{array}$ & High & High / medium \\
\hline
\end{tabular}


Table 3: Continued.

\begin{tabular}{|c|c|c|}
\hline IDDS & Norway & Singapore \\
\hline \multicolumn{3}{|c|}{ Collaborating people continued. } \\
\hline $\begin{array}{l}\text { Importance of public } \\
\text { projects for construction } \\
\text { industry }\end{array}$ & Very important & Important \\
\hline $\begin{array}{l}\text { BIM maturity/ } \\
\text { technology awareness }\end{array}$ & $\begin{array}{l}\text { High, } \\
\text { and with focus on } \\
\text { openBIM/IFC-format }\end{array}$ & $\begin{array}{l}\text { High, } \\
\text { but with focus on use of } \\
\text { Autodesk software }\end{array}$ \\
\hline \multicolumn{3}{|c|}{ Interoperable technology } \\
\hline Type of technology & Model server & Model server \\
\hline $\begin{array}{l}\text { Input } \\
\text { - specification of file } \\
\text { format }\end{array}$ & $\begin{array}{l}\text { Text informs } \\
\text { Files as attachment; PDF } \\
\text { (preferred), doc and jpg }\end{array}$ & $\begin{array}{l}\text { File based-view of } \\
\text { building models }\end{array}$ \\
\hline Processing & Input of text in forms & Input of text in forms \\
\hline $\begin{array}{l}\text { Validation } \\
\text { (checking/control) }\end{array}$ & $\begin{array}{l}\text { Validation of correct } \\
\text { filled-in forms } \\
\text { No check of attached file } \\
\text { - manual operation }\end{array}$ & $\begin{array}{l}\text { Validation of correct } \\
\text { filled-in forms } \\
\text { Support for check of } \\
\text { attached files of building } \\
\text { models } \\
\text { - semi-manual operation }\end{array}$ \\
\hline Presentation & $\begin{array}{l}\text { Not included } \\
\text { Read PDF/jpg files of } \\
\text { drawings }\end{array}$ & $\begin{array}{l}\text { Use of Fornax viewer } \\
\text { for presentation of } \\
\text { model. Enable free } \\
\text { choice of sections. }\end{array}$ \\
\hline \multicolumn{3}{|c|}{ Integration with other registry: } \\
\hline - cadastre & Not included & Included \\
\hline - business registry & Included & Included \\
\hline - other public authorities & Not included & Included \\
\hline $\begin{array}{l}\text { BIM implementation in } \\
\text { industry }\end{array}$ & High & High \\
\hline $\begin{array}{l}\text { OpenBIM } \\
\text { implementation }\end{array}$ & High & Limited \\
\hline
\end{tabular}

components. An impact of this will be that lessons learned must be funded on understanding of why they have chosen to do, then on copying what done for national use.

\section{Discussion}

The intention with this study was to identify lessons learned from successful solutions.

It is not a comparative study trying to identify the best solutions from each country - and then recommend combining these into the "best" solution - be we "copied" for national implementation. The construction industry - and related research his has traditionally been done with focus on technology by use of defined criteria. Other "soft components" has often been more randomly examined. The 
challenge is to find applicable framework for the entire construction industry, and in this respect was the CIB Priority theme IDDS framework selected as a framework in this study. Other theories within innovation, transfer of technology, institutionalising, maturity etc. can contribute to better understanding of elements involved. Whether use of IDDS, or IDDS alone without support from other theories give the complete picture can be discussed. On the other hand has use of theoretical framework contributed to give counterweight to the dominating focus on technology.

\section{Conclusion}

This study identify similarities and differences in components included in the Norwegian and the Singapore solution for digital processing of building permit applications. Both solutions has been in practical use for over ten years and undergone several revision to bee update to current needs. Both solutions are based on model server technology. All countries have approval of building permit as mandatory part of a project. Global use of digital solutions should therefor been expected, and this study should have identified the most important components. However, this is not the situation. Use of the IDDS framework has identified that it is the balance between the three perspectives; Integrated process, Collaborating people and Interoperable technology, which have contributed to the success of these two solutions. Lessons learned are that increased understanding of the balance between these perspectives is the much more important criteria for success, than initiatives to copy the "best" solution, or component for another country. There is no, or limited, indication that Norway and Singapore have copied directly each other's solutions. They have been aware of each other, an in this respect can transfer of knowledge be regarded as an important contribution. Implementation must be founded on adaptations to national situation and constraints. Solutions in Norway and Singapore have undergone several revision to be update to technology, regulation and digital maturity. Continues development must be included as part of introducing digital solutions processing of building permit applications. Experiences from use of the IDDS framework recommend this used for developing increased understanding. Traditionally has countries introducing new technology based solutions been regarded as pioneers. However, technology alone do not contribute to transfer of solutions of public BIM-based model checking solutions. Future pioneer will be countries that balance different perspectives to enable solutions for with positive cost/benefit for the life cycle of the solution.

\section{Further research/studies}

Experiences from this study indicate need for a more integrated research approach for analysing of multiple components and their relationships. Further studies will focus on the relation between the three perspectives (Integrated process, Collaborating people and Interoperable technology) and the three imperatives (Building Information Modelling, Knowledge management and Integrated project 
delivery) to understand how increased transfer can be supported. Further studies will focus on identifying; Drivers for change, Enablers, Barriers and Opportunities. This study can include all countries planning to develop solutions. The important approach in future research will give priority to explore impact of change and their direct, indirect, derived and potential effects.

\section{References}

[1] McGraw Hill SmartMarket Report, McGraw Hill Construction, 2012. download.autodesk.com/us/bim_infra/Business_Value_of_BIM_for_Infra structure_SMR_2012.pdf

[2] Hjelseth, E., BIM-based model checking (BMC), Building Information Modeling - Applications and Practices, eds. R. Issa and S. Olbina, American Society of Civil Engineer, Soft Cover ISBN: 9780784413982, Ebook (PDF) ISBN: 9780784479131, pp. 33-61, 2015. dx.doi.org/10.1061/ 9780784413982.ch02

[3] Nisbet, N., Wix J. \& Conover, D. The future of virtual construction and regulation checking, Virtual futures for design, construction \& procurement, eds. P. Brandon and T. Kocatiirk, Blackwell Publishing Ltd, ISBN-13:978-1-4051-7024-6, pp. 241-250, 2008.

[4] Hjelseth, E., Integrated approach for development of automatic building permission systems, Proc. of the 19th International CIB World Building Congress, eds. S. Kajewski, K. Manley and K. Hampson, Queensland University of Technology, ISBN: 978-0-9875542-1-5, paper 92, 2013.

[5] Refvik, R., ByggNett - Status survey of solutions and issues relevant to the development of ByggNett. Norwegian Building Authority, 2014. dibk.no/globalassets/byggnett/byggnett_rapporter/byggnett-statussurvey.pdf

[6] DIBK, Teknisk informasjon om ByggSøk, Norwegian Building Authority http://www.dibk.no/no/Byggsok/Om-ByggSok/Teknisk-informasjon-omByggSok/

[7] ByggNett - A strategy for the future of digital construction sector (Norwegian), Norwegian Building Authority, 2014. dibk.no/globalassets/ byggnett/byggnett_rapporter/byggnett-strategi-1.0.pdf

[8] CORENET, e-Submission System in Singapore. https://www.corenetess.gov.sg/ess/

[9] Planning Portal, UK Government's online planning and building regulations resource for England and Wales. www.planningportal.gov.uk/

[10] Choi, J., Choi, J., Cho, G. \& Kim, I., Development of Open BIM-based Code Checking, Modules for the Regulations of the Fire and Evacuation, buildingSMART Korea and Kyung Hee University, 2012. www.irbnet.de/daten/iconda/CIB_DC25807.pdf

[11] Hjelseth, E., Foundations for BIM-based model checking systems, Transforming regulations into computable rules in BIM-based model checking systems. PhD Thesis number 2015:54 (in print), Department of 
Mathematical Sciences and Technology, Norwegian University of Life Sciences, ISBN 978-82-575-1294-1, pp. 1-198, 2015.

[12] The Research Roadmap for IDDS - Integrated Design and Delivery Solutions, CIB publication 370, Priority theme in CIB, International council for research and innovation in building and construction, 2014. cibworld.xs4all.nl/dl/publications/pub_370.pdf

[13] Bringedal, T., Are we aiming at targets? Presentation at the DIFI Digitization Conference, June 16 2015 in Oslo, Head of Department, Department of eGovernment (DIFI), Oslo, Norway.

[14] Peppard, J., Designed to Fail: Why IT Investments Underachieve and What to do About It? Presentation at the DIFI Digitization Conference, June $16^{\text {th }}$ 2015 in Oslo, Professor at European School of Management and Technology, Berlin, Germany.

[15] Merschbrock, C. and Munkvold, B., E. A Research Review on Building Information Modeling in Construction - An Area Ripe for IS Research, Communications of the Association for Information Systems: Vol. 31, Article 10. 2012.

[16] Dealing with Construction Permits in in 2012 in Norway, World Bank Group, www.doingbusiness.org/data/exploreeconomies/norway/dealingwith-construction-permits/

[17] Norway from Wikipedia, en.wikipedia.org/wiki/Norway

[18] Byggenæringen i tall (Construction industry in numbers), Byggnoeringens landsforbund. bnl.no/dette-er-bnl/aktuelt/byggenaringen-i-tall/

[19] BIM Overlay to the RIBA Outline Plan of Work, Bew-Richards BIM Maturity Model, Royal Institute of British Architects, eds. D. Sinclair, ISBN 978-1-85946-467-0, 2012.

[20] Digital built Britain - level 3 strategy UK construction industry: digital technology (Policy paper), Department for Business, Innovation \& Skills, UK. Www.gov.uk/government/publications/uk-construction-industrydigital-technology

[21] Dealing with Construction Permits in 2012 in Singapore, World Bank Group, www.doingbusiness.org/data/exploreeconomies/singapore/dealingwith-construction-permits/

[22] BCA Approval - Listing of Approved Plans and Permits in Singapore in 2014, Building and Construction Authority in Singapore. www.bca.gov.sg/eservice/ShowDetails.aspx

[23] Public sector projects to sustain construction demand in 2015, Building and Construction Authority. www.bca.gov.sg/Newsroom/pr08012015 BCA.html

[24] Labour Market Statistical Information, Ministry of Manpower in Singapore. stats.mom.gov.sg/Pages/Home.aspx

[25] Singapore from Wikipedia, en.wikipedia.org/wiki/Singapore

[26] Dimyadi, J. \& Amor, R., Automated Building Code Compliance Checking - Where is it at? Proceedings of the 19th International CIB World Building Congress, eds. S. Kajewski, K. Manley and K. Hampson, Queensland University of Technology, ISBN: 978-0-9875542-1-5, Paper 241, 2013. 